\title{
The Influence of Metallic Oxides Formed by Repetitive Cyclic Voltammetry or Controlled Potential in the Reactivity of Ir/Hg System
}

\author{
E. Milaré, E. Y. Ionashiro, Y. Maniette, A. V. Benedetti and F. L. Fertonani * \\ Instituto de Química, Universidade Estadual Paulista, Araraquara, São Paulo, C.P. 355, \\ CEP 14.801-970, Brazil
}

Received 10 September 2002; accepted in revised form 22 November 2002

\begin{abstract}
Cyclic voltammetry and controlled potential electrolysis, and other analytical techniques were used to study the reactions of mercury with iridium oxides formed by repetitive cyclic voltammetry (RCV) or by controlled potential electrolysis (CPE) on pure iridium substrate. The oxides were formed in a $\mathrm{Hg}(\mathrm{I})$-containing solution. The SEM images, XPS spectra and CV obtained after the RCV treatment showed a more attacked surface with less mercury on the Ir. On the contrary, the SEM images, XPS spectra and the CV for the electrode prepared by CPE indicated a less attacked surface with more Hg. The oxides formed when the CPE condition was applied inhibited the UPD of mercury.
\end{abstract}

Keywords: iridium, mercury, cyclic voltammetry.

\section{Introduction}

Pure platinum, rhodium and iridium, and alloys of platinum-iridium and platinum-rhodium have been widely used to prepare microelectrodes [1-6], catalysts used in petroleum cracking industry [7-8]. It is well known that when solid metals are placed in contact with mercury, a variety of physicochemical changes may occur, e.g., complete or partial dissolution of the solid, intermetallic compounds formation at the liquid-solid interface or in the solution, grain

\footnotetext{
${ }^{*}$ Corresponding author. E-mail address: fertonan@iq.unesp.br
} 
boundary grooving, and liquid metal embrittlement. Such changes may also cause structural deterioration of the solid surface [2-6].

Considering the importance of the development of new substrates with high resistance to mercury amalgamation, $\operatorname{Pt}-\operatorname{Ir}_{(20}$ wt.\%) has been suggested as an appropriate substrate for mercury deposition due to its surface is not scarred by interaction with mercury [9]. However, intermetallic compounds such as $\mathrm{PtHg}_{4}$ and $\mathrm{PtHg}_{2}$ on the Pt-Ir(20 wt.\%) alloy surface were identified based on X-ray diffraction results [4]. The resulting changes in the surface morphology were investigated by optical interferometry and SEM images, and the changes in the Hg-noble alloy interaction energy by XPS. The XPS results were interpreted considering a model where the electrode/solution interphase is composed by different phases including a three layered region structure, containing at least two Pt-Hg intermetallics, $\mathrm{PtHg}_{4}$ and $\mathrm{PtHg}_{2}$, and a substrate modified region, iridium rich [4].

Iridium has been used because of its low solubility in mercury and its nonchemical surface interaction with mercury. However, when the anodic stripping or thermal analysis techniques were used to remove mercury, an increase in the electrode surface area was observed, which was attributed to the mercurysubstrate interactions, destabilizing the electrode surface [5].

In the present work, films of mercury were electrodeposited on pure iridium foils submitted to a repetitive cyclic voltammetry or controlled potential electrolysis at $0.9 \mathrm{~V} / \mathrm{Ag} / \mathrm{AgCl}, \mathrm{KNO}_{3}$. The new generated surfaces were studied using $\mathrm{CV}$, EDX, SEM, Surface Mapping, X-ray diffractometry and XPS.

\section{Experimental}

Pure iridium foils $\left(80 \mathrm{~mm}^{2}\right.$ ) were polished with $\mathrm{Al}_{2} \mathrm{O}_{3}$ (particles size $<0.3 \mu \mathrm{m}$ ) in aqueous suspension and washed in $\mathrm{HNO}_{3}: \mathrm{H}_{2} \mathrm{O}(50 \% \mathrm{v} / \mathrm{v})$ using an ultrasonic bath. Afterwards, thin films of $\mathrm{Ir}$ oxides were generated in $\mathrm{Hg}(\mathrm{I})$-containing solution using repetitive cyclic voltammetry (RCV) or controlled potential electrolysis (CPE). 
All electrochemical measurements were performed using an ECOCHEMIE Potentiost-Galvanostat PGSTAT10 and a matrix exchange cell $(10 \mathrm{~mL})$ with: 1Ir work electrode $\left(c a .85 \mathrm{~mm}^{2}\right) ; 2$ - a large platinum counter-electrode $(\mathrm{A}=0.1$ $\left.\mathrm{cm}^{2}\right)$; 3- $\mathrm{Ag} / \mathrm{AgCl}, \mathrm{KNO}_{3 \text { (sat) }}$ as reference electrode; 4- a degassed solution containing $1.40 \mathrm{mmol} \mathrm{Hg}_{2}{ }^{2+}+1.00 \mathrm{M} \mathrm{KNO}_{3} / \mathrm{HNO}_{3}(\mathrm{pH} 1)$. Two electrochemical treatments were applied on the electrode: (I) repetitive cyclic voltammograms (1000 cycles) at $\mathrm{v}=1 \mathrm{Vs}^{-1}$ in $\mathrm{KNO}_{3}$ and $\mathrm{KNO}_{3} / \mathrm{Hg}_{2}{ }^{2+}$ solution in a potential interval of $\mathrm{E}_{\mathrm{i}}=\mathrm{E}_{\mathrm{f}}=0.5 \mathrm{~V}, \mathrm{E}_{\lambda, 1}=-0.35 \mathrm{~V} ; \mathrm{E}_{\lambda, 2}=0.85 \mathrm{~V}$; (II) cyclic voltammograms (2 cycles at $10 \mathrm{mV} \mathrm{s}^{-1}$ ) followed by applying a controlled potential, $\mathrm{E}_{\text {dep. }}=0.9 \mathrm{~V}$ for 1 minute. The surface of the samples were examined by JEOL JSM-T330A microscope coupled to a NORAN system to obtain SEM images and EDX microanalysis before and after the electrochemical experiments. The X-ray diffractograms were recorded with a diffractometer HIGAKU RINT 2000 with a rotatory anode and all data obtained were treated using AFPAR and DHKL softwares [10]. The XPS analysis were accomplished by irradiating the sample with monoenergetic soft X-ray $(\mathrm{Al} \mathrm{K} \alpha=1486.6 \mathrm{eV})$ in a Physical Electronics PHI 5500 system.

\section{Results and Discussion}

Figure 1 shows the cyclic voltammograms (CV) recorded at $50 \mathrm{mV} / \mathrm{s}$ for $\mathrm{Ir}-\mathrm{Hg}$ system before and after RCV: a) before $\mathrm{RCV}$ in $\mathrm{KNO}_{3} / \mathrm{HNO}_{3}$ solution; b) after $\mathrm{RCV}$ in $\mathrm{KNO}_{3} / \mathrm{HNO}_{3}$ solution; c) before $\mathrm{RCV}$ in $\mathrm{Hg}(\mathrm{I})$ solution $\left(\mathrm{C}_{\mathrm{Hg}(\mathrm{I})}=\right.$ $\left.1.23 \times 10^{-4} \mathrm{~mol} \mathrm{~L}^{-1}\right)$; d) before RCV in $\mathrm{Hg}(\mathrm{I})$ solution $\left(\mathrm{C}_{\mathrm{Hg}(\mathrm{I})}=6.12 \times 10^{-4} \mathrm{~mol} \mathrm{~L}^{-1}\right)$; e) after $\mathrm{RCV}$ in $\mathrm{Hg}(\mathrm{I})$ solution $\left(\mathrm{C}_{\mathrm{Hg}(\mathrm{I})}=6.12 \times 10^{-4} \mathrm{~mol} \mathrm{~L}^{-1}\right)$.

$\mathrm{CV}$ (a) and (b) in Fig. 1 represent anodic and cathodic limit potentials to initiate the water decomposition on Ir. It is possible to observe that the limit potential changes from $c a .700 \mathrm{mV}$ to $c a .650 \mathrm{mV}$, suggesting that the $\mathrm{RCV}$ treatment made easier the oxygen evolution and no changes were observed in the cathodic limit (ca. $150 \mathrm{mV})$. It was also observed a decrease in the charge of the cyclic voltammogram recorded after RCV. 


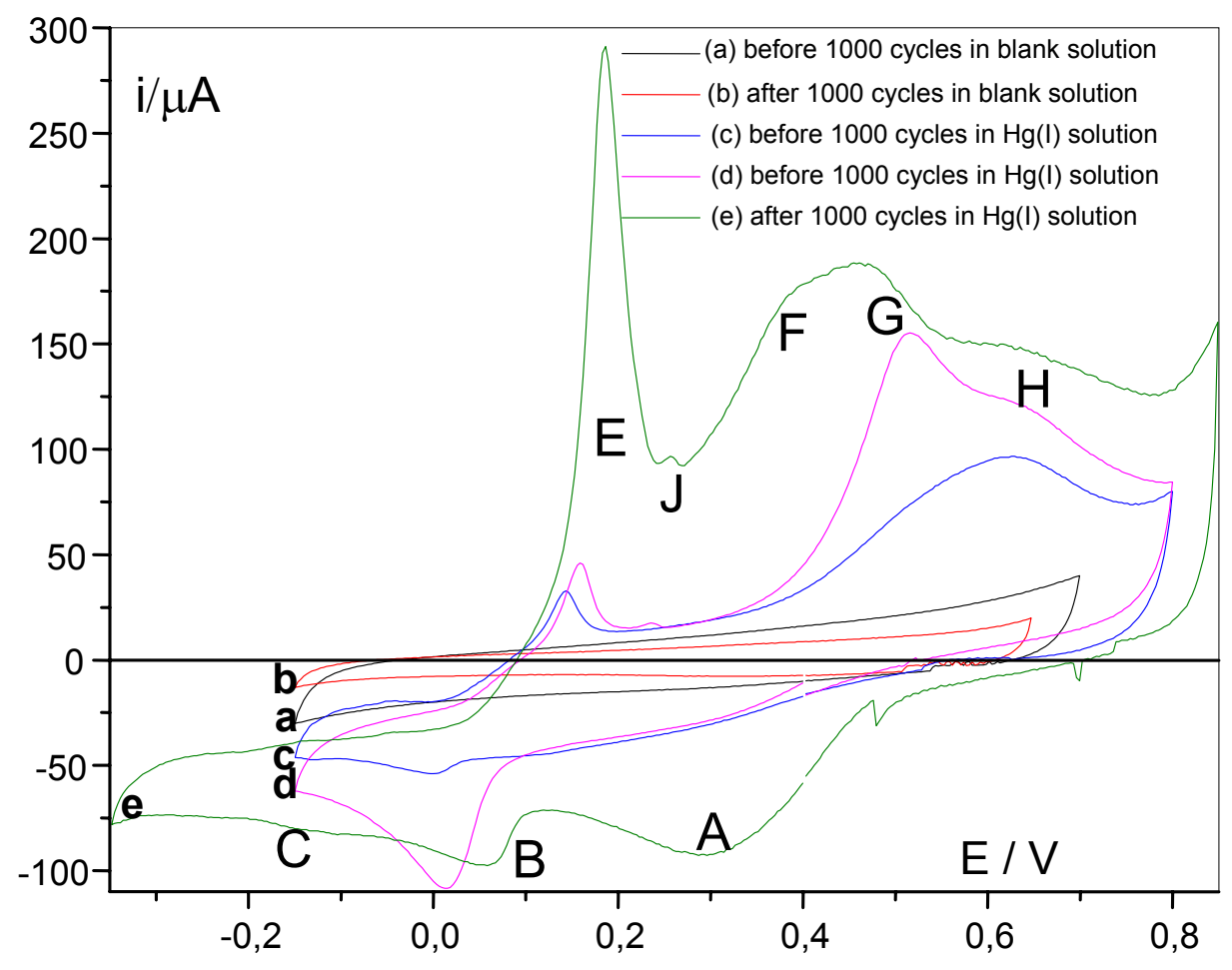

Figure 1. Cyclic voltammograms for Ir recorded at $50 \mathrm{mV} / \mathrm{s}$ : a) before RCV in $\mathrm{KNO}_{3} / \mathrm{HNO}_{3}$ solution; b) after $\mathrm{RCV}$ in $\mathrm{KNO}_{3} / \mathrm{HNO}_{3}$ solution; c) before $\mathrm{RCV} \mathrm{Hg}$ (I), $\mathrm{C}_{\mathrm{Hg}(\mathrm{I})}=1.23 \times 10^{-4} \mathrm{~mol} \mathrm{~L}^{-1}$; d) $\mathrm{C}_{\mathrm{Hg}(\mathrm{I})}=6.12 \times 10^{-4} \mathrm{~mol} \mathrm{~L}^{-1}$; e) after $\mathrm{RCV}$ in solution containing $\mathrm{Hg}(\mathrm{I}), \mathrm{C}_{\mathrm{Hg}(\mathrm{I})}=6.12 \times 10^{-4} \mathrm{~mol} \mathrm{~L}^{-1}$.

In $\mathrm{Hg}(\mathrm{I})$-containing solution the cathodic scan recorded before (d) and after (e) RCV treatment showed the following changes: the UPD potential region was enlarged in $100 \mathrm{mV}$ and the volumetric mercury deposition peak shifted anodically about $10 \mathrm{mV}$. It is also observed a significant change in the limit potential for the hydrogen evolution from $-0.15 \mathrm{~V}$ (before) to $-0.35 \mathrm{~V}$ (after) the RCV treatment.

For all $\mathrm{CV}$ in the anodic scan 4 peaks were observed, which were attributed to the following processes: E) oxidation of volumetric mercury [11-13]; F and G) oxidation of UPD mercury (only peak $\mathrm{F}$ is reported in literature [12]); H) oxidation of mercury present in the underlayers of the substrate forming a solid solution with iridium. The formation of oxides of mercury and iridium (confirmed by XRD) and the mercury removal from the substrate (peak $\mathrm{H}$ ) has 
caused an increase in the capacitive current. It could be probably due to an increase of the electrode surface area.

The RCV treatment when performed in $\mathrm{Hg}(\mathrm{I})$-containing solution caused an increase of capacitive current, and shifted the oxygen and hydrogen evolution potentials to more anodic and cathodic values, respectively. The resulting substrate is showed in Fig. 2. Comparing Figs. 2a and b with Fig. 2c (control region, without attack), it can be observed an increase in the surface roughness.

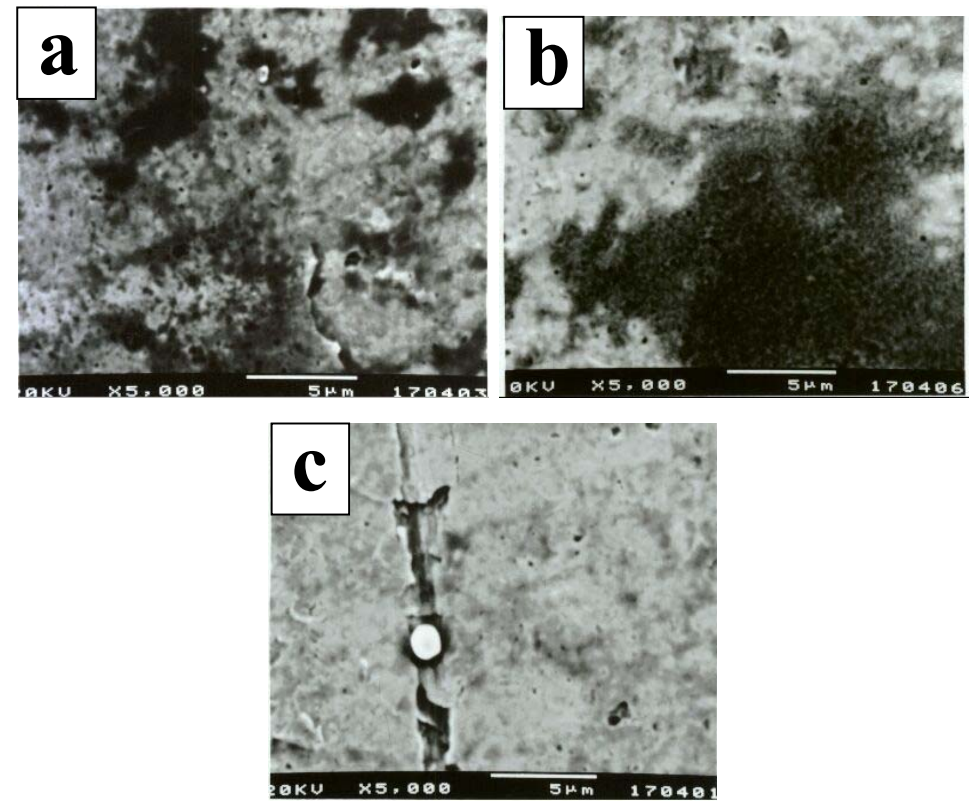

Figure 2. SEM images obtained for $\mathrm{Ir}-\mathrm{Hg}$ system electrode submitted to 1000 scans, at $\mathrm{v}=1 \mathrm{~V} \mathrm{~s}^{-1}$ in $\mathrm{Hg}(\mathrm{I})$-containing solution $\left(\mathrm{C}_{\mathrm{Hg}(\mathrm{I})}=6.12 \times 10^{-4} \mathrm{~mol} \mathrm{~L}^{-1}\right)$. a) and $\mathrm{b}$ ) represent the regions attacked by $\mathrm{Hg}$; c) the control region. Electron beam energy was $30 \mathrm{kV}$ and the amplification $5000 \mathrm{X}$.

The EDX microanalysis for this sample did not reveal mercury in the substrate when a SEM microscope was used, but mercury was detected using the EDX coupled to the Transmission Electron Microscope (Fig. 3), indicating a mercury penetration into the substrate. The darkness field images associated with electron diffraction technique showed monocrystalline regions with local deformation caused, certainly, by the occupation of specific sites in the substrate by the $\mathrm{Hg}$ (Fig. 4a). The darkness field technique evidenced small changes in the atomic plans orientation. The rectangular figures oriented in the same direction (Fig. 4a) suggest the insertion of atoms different from those ones present in the substrate 
(in this case, the $\mathrm{Hg}$ ). These rectangular figures suggest the monocrystal formation, which was confirmed by the electron diffraction technique (Fig. 4b).

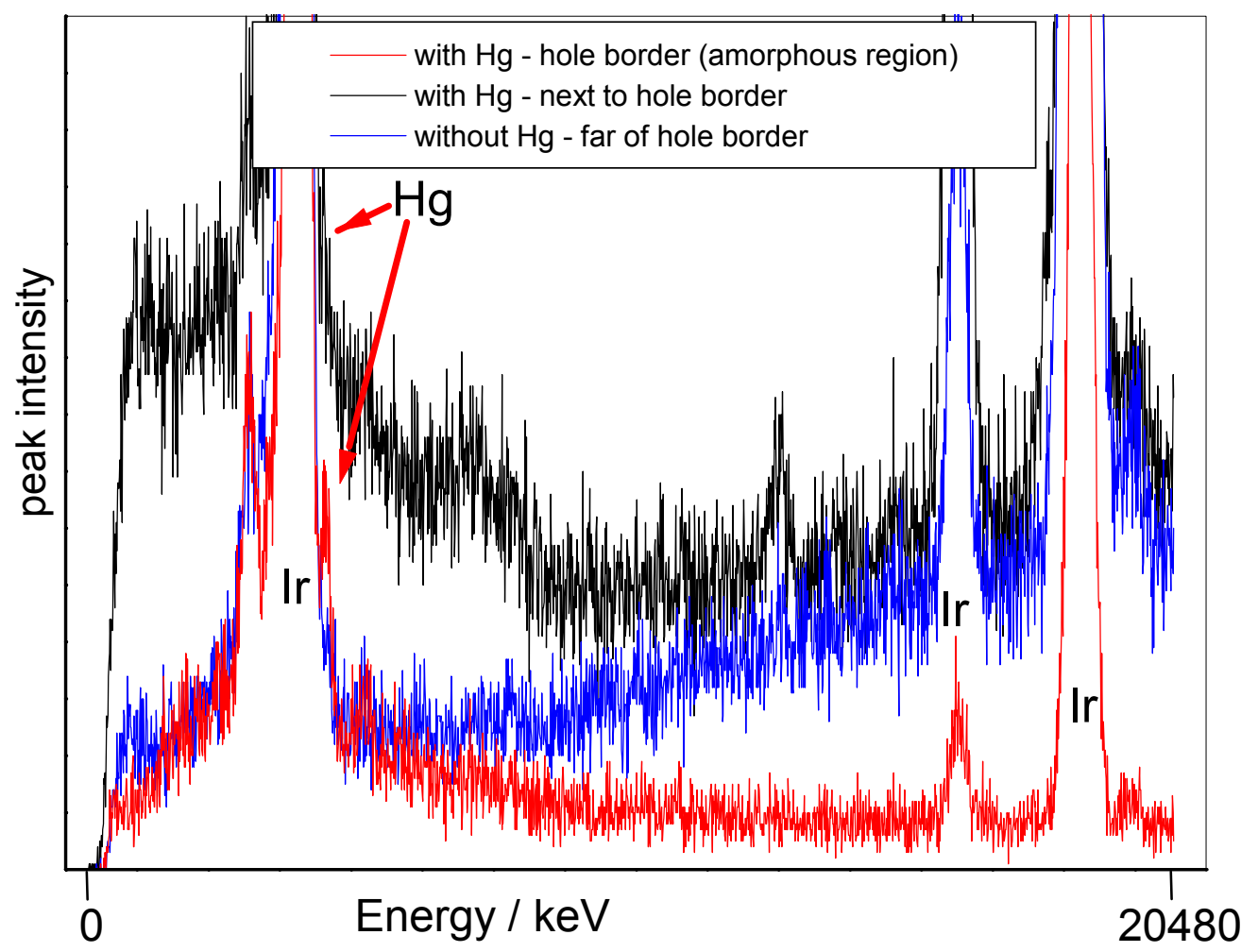

Figure 3. EDX microanalysis obtained with EDX system coupled to the Transmission Electron Microscope (TEM) for Ir-Hg system electrode submitted to 1000 scans, at $\mathrm{v}=1$ $\mathrm{V} \mathrm{s}^{-1}$ in $\mathrm{Hg}(\mathrm{I})$-containing solution $\left(\mathrm{C}_{\mathrm{Hg}(\mathrm{I})}=6.12 \times 10^{-4} \mathrm{~mol} \mathrm{~L}^{-1}\right)$.
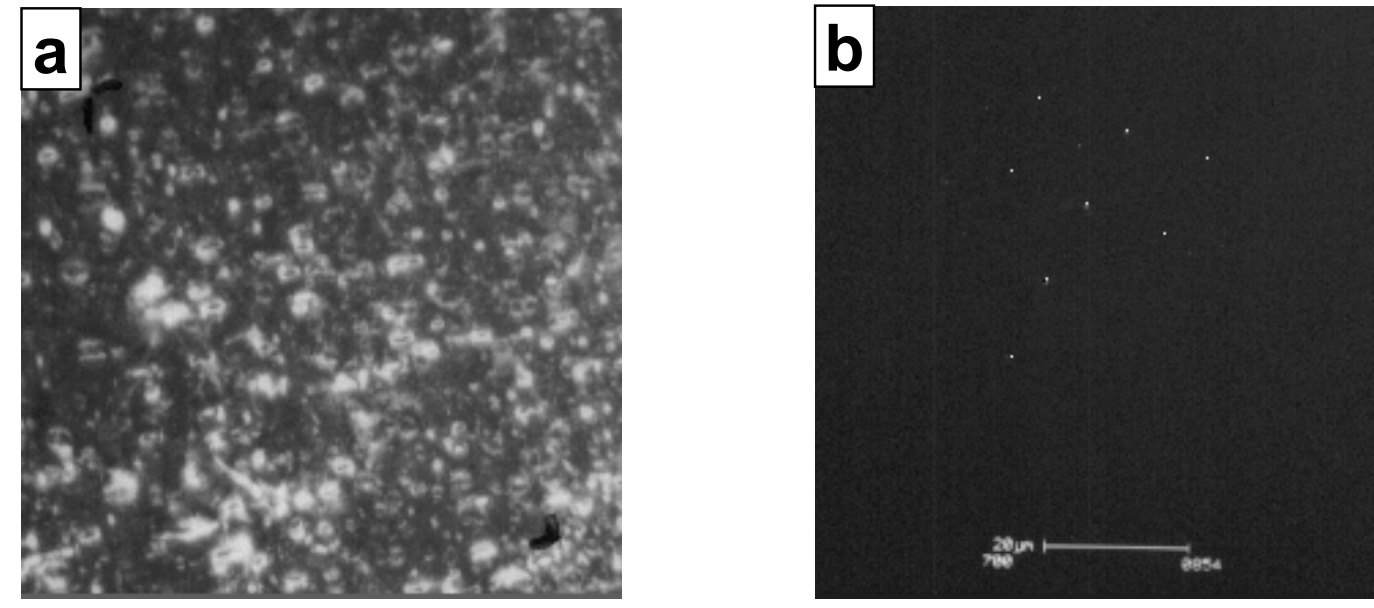

Figure 4. TEM images obtained for Ir-Hg system electrode submitted to 1000 scans, at $\mathrm{v}=1 \mathrm{~V} \mathrm{~s}^{-1}$ in $\mathrm{Hg}(\mathrm{I})$-containing solution $\left(\mathrm{C}_{\mathrm{Hg}(\mathrm{I})}=6.12 \times 10^{-4} \mathrm{~mol} \mathrm{~L}^{-1}\right)$. a) darkness field images; b) electron diffraction. 
Fig. 5a shows the CV (2 consecutive cycles) and the third cycle recorded after holding the potential at $+0.9 \mathrm{~V}$ for 1 minute. The same anodic peaks obtained after the RCV treatment were observed. A low cathodic current (before UPD region, $0.5 \mathrm{~V} \leq \mathrm{E} \leq 0.9 \mathrm{~V}$ ) corresponding to the reduction of iridium oxides was also observed. These oxides could inhibit the UPD process and anticipate the $\mathrm{H}_{2}$ discharge from $c a$. $-0.5 \mathrm{~V}$ to $c a$. $-0.3 \mathrm{~V}$. No changes in the anodic scan were observed.

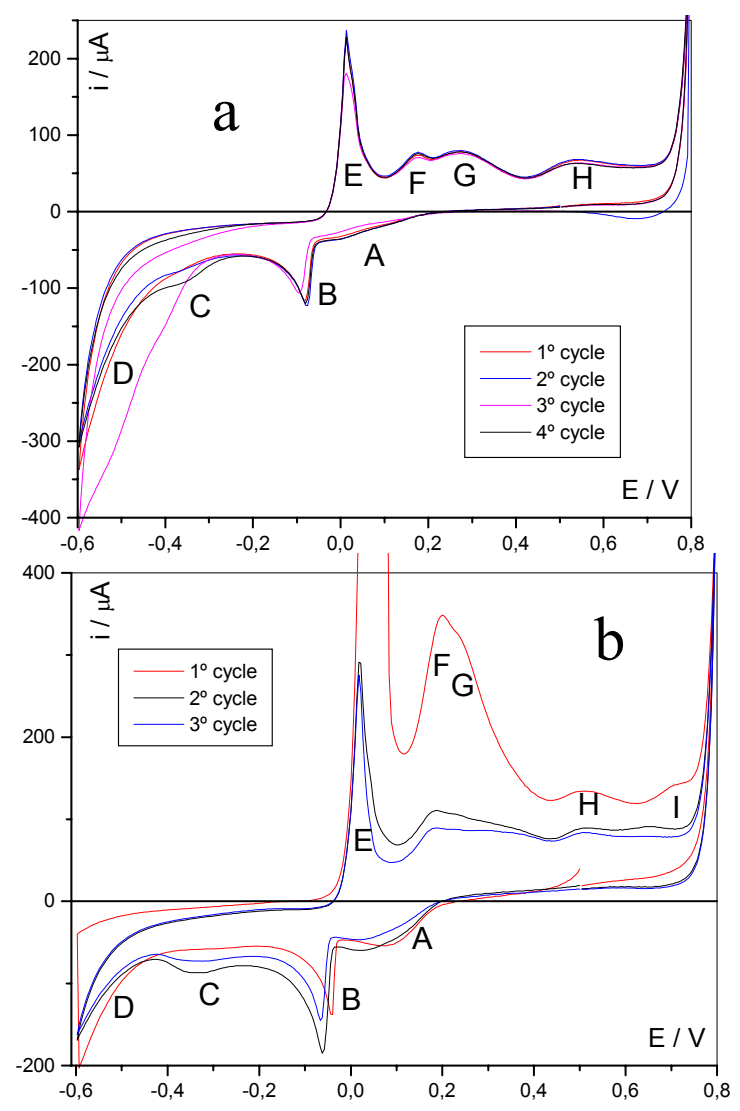

Figure 5. Cyclic voltammograms for Ir recorded at $10 \mathrm{mV} / \mathrm{s}$ in $\mathrm{Hg}(\mathrm{I})$-containing solution $\left(\mathrm{CHg}(\mathrm{I})=6.12 \times 10^{-4} \mathrm{~mol} \mathrm{~L}^{-1}\right)$ : a) before and after $\mathrm{CPE}$ in $\mathrm{E}=0.9 \mathrm{~V}$; $\left.\mathrm{b}\right)$ before and after $\mathrm{CPE}$ in $\mathrm{E}=-0.5 \mathrm{~V}$.

Fig. $5 \mathrm{~b}$ shows the $\mathrm{CV}$ obtained before and after applying $-0.5 \mathrm{~V}$ for 1 minute $\left(\mathrm{H}_{2}\right.$ discharge region). In this condition the $\mathrm{Hg}$ deposition on the substrate and the oxides reduction occurred simultaneously. All anodic peaks previously described and also an additional anodic peak (peak $\mathrm{I}, \mathrm{E}=0.71 \mathrm{~V}$ ) were observed in the anodic scan. The last one (peak I) is probably correspondent to the peak $\mathrm{C}(\mathrm{E}=$ - 
$0.36 \mathrm{~V}$ ) in the cathodic scan. This peak is not clearly seen in Fig. 5a because the surface presents many oxides. Increasing the number of scans, the oxides removal occurs, permitting an increase of peak $\mathrm{C}$ and, consequently, an increase of peak I.

Fig. 6 shows the SEM images for the sample after applying $-0.6 \mathrm{~V}$ for 1 minute (Fig. 6a) and for the control region (Fig. 6b). The mapping of $\mathrm{Hg}$ (Fig. 6c) shows a homogeneous distribution of $\mathrm{Hg}$ on the attacked region. The XPS analysis of the attacked region showed $\mathrm{Hg}$ in the Ir substrate up to the fifth atoms layer (ca. $50 \mathrm{~nm}$ depth) reaching 3 at.\% of $\mathrm{Hg}$, possibly forming a solid solution with the substrate.

The XPS analysis does not detect $\mathrm{Hg}$ in the samples submitted to the RCV treatment.
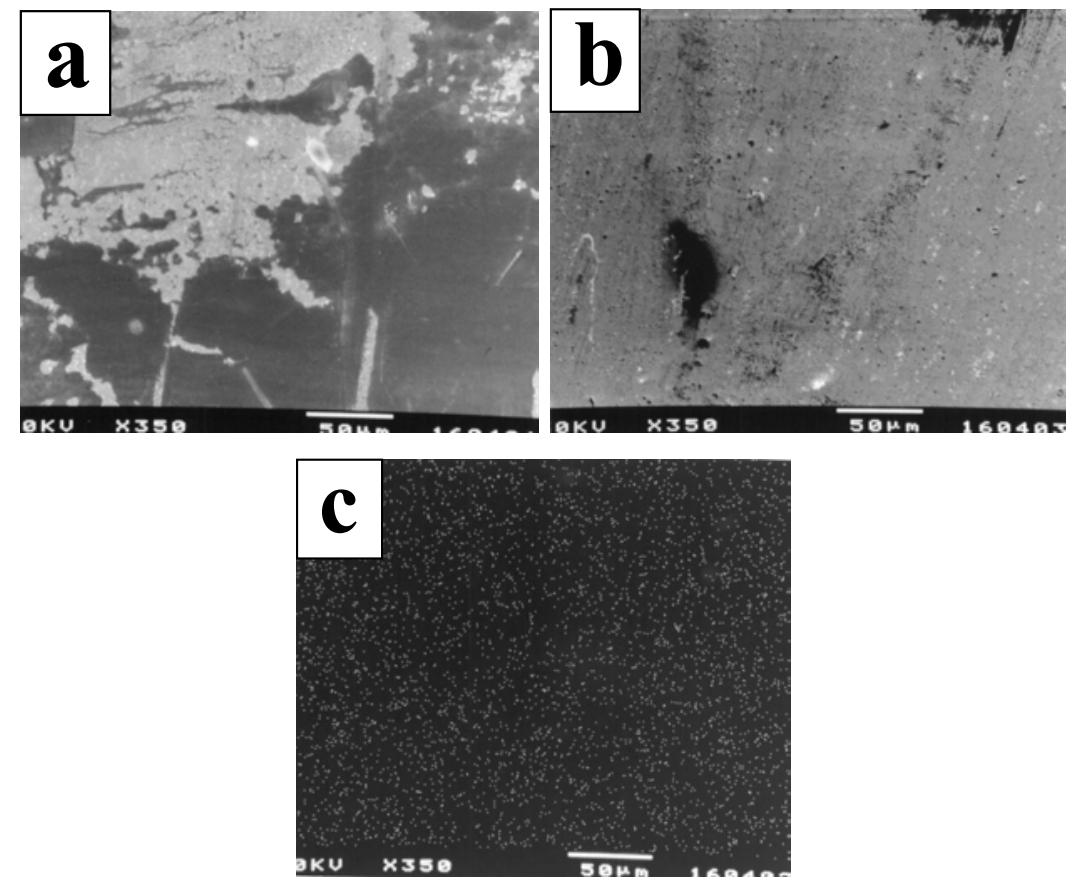

Figure 6. SEM images obtained for $\mathrm{Ir}-\mathrm{Hg}$ system electrode submitted to controlled electrolysis by 1 minute $(\mathrm{E}=0.9 \mathrm{~V})$ in $\mathrm{Hg}(\mathrm{I})$-containing solution $\left(\mathrm{C}_{\mathrm{Hg}(\mathrm{I})}=6.12 \times 10^{-4} \mathrm{~mol} \mathrm{~L}^{-1}\right)$. a) represents the regions attacked by $\mathrm{Hg}$; b ) the control region. Electron beam energy was $30 \mathrm{kV}$ and the amplification $5000 \mathrm{X}$. 


\section{Conclusion}

The RCV and potentiostatic treatments used in this work lead to a different attack intensity of the electrode surface and the formation of new anodic current peaks (peaks $\mathrm{H}$ and I).

When $-0.6 \mathrm{~V}$ was applied to the electrode immersed in a $\mathrm{Hg}(\mathrm{I})$-containing solution peaks $\mathrm{F}$ and $\mathrm{H}$ were better defined and a new peak (peak I) appeared, probably due to the partial reduction of iridium oxides. The iridium oxides formation facilitates the mercury attack to iridium surface.

The Hg UPD on Ir occurs at open circuit potential, making difficult or almost impossible to use this substrate in solution containing $\mathrm{Hg}$ ions without the contribution of $\mathrm{Hg}$ UPD process. The formation of iridium oxides on the substrate inhibits the UPD process.

\section{Acknowledgement}

Authors thank to FAPESP (Fundação de Amparo à Pesquisa do Estado de São Paulo) and CNPq/PIBIC (Conselho Nacional de Desenvolvimento Científico e Tecnológico / Programa Institucional de Bolsas de Iniciação Científica) for the financial support. Authors also thank the LIEC (Laboratório Interdisciplinar de Estudos de Cerâmica) for the X-ray analysis and the Servèis Cientific Tècnics of the Universitat de Barcelona for the XPS analysis.

\section{References}

1. F.L. Fertonani, A.V. Benedetti, M. Ionashiro. Thermochim, Acta 265 (1995) 151.

2. F.L. Fertonani, M. Ionashiro, P. Melnikov, F. Sanz, A.V. Benedetti, Proceedings of XII Congreso Iberoamericano y IX Encontro Venezolano de Electroquimica, Merida, Venezuela, (1996) 416.

3. E. Milaré, F.L. Fertonani, M. Ionashiro, A.V. Benedetti, P. Melnikov, Proceedings of XIII Congreso de la Sociedad Iberoamericana de Electroquimica, Viña del Mar (1998) 140.

4. F.L. Fertonani, A.V. Benedetti, J. Servat, J. Portillo, F. Sanz, Thin Solid Films 1 (1999) 341. 
5. F.L. Fertonani, E. Milaré, A.V. Benedetti, M. Ionashiro, J. Therm. Anal. Cal. 67 (2002) 403.

6. E. Milaré, F.L. Fertonani, M. Ionashiro, A.V. Benedetti, J. Therm. Anal. Cal. $59(2000) 617$.

7. R.W. Joyner, E.S. Shpiro, Catalysis Letter 9 (1991) 239.

8. M. Barlow, P.J. Planting, Z. Metallkd 60 (1969) 292.

9. C. Wechter, J. Osteryoung, Anal. Chem. Acta 234 (1990) 275.

10. AFPAR and DHKL programs, B. Lestienne, CNRS (1990).

11. M.A. Nolan, S.P. Kounaves, J. Electroanal. Chem. 453 (1998) 39.

12. S.P. Kounaves, J. Buffle, J. Electrochem. Soc. 133 (1986) 2495.

13. S.P. Kounaves, J. Buffle, J. Electroanal. Chem. 216 (1987) 53. 